\title{
Detection of Herpesvirus anguillae infection in eel using in situ hybridization
}

\author{
By H. H. Shih ${ }^{1}$, C. W. Hu ${ }^{1}$ and C. S. Wang ${ }^{2}$ \\ ${ }^{1}$ Department of Zoology, National Taiwan University, Taipei, Taiwan; ${ }^{2}$ Department of Life Science, National University of \\ Kaohsiung, Kaohsiung, Taiwan
}

\begin{abstract}
Summary
A nucleic acid probe for the Herpesvirus anguillae (HVA) Taiwan isolate was constructed using recombinant DNA techniques. This probe consisted of a specific viral DNA fragment (1550 bp) generated by digestion of HVA DNA with the restriction enzyme HindIII, and labeled non-radioactively with digoxigenin (DIG). The probe was used to detect the HVA genome from HVA-infected cell cultures and tissue specimens prepared from infected eels, using either dot blot or in situ hybridizations.
\end{abstract}

\section{Introduction}

Herpesvirus infection in eels was first reported by Sano et al. (1990). A herpesvirus characterized and designated Herpesvirus anguillae (HVA) was isolated in Japan from farmed diseased European eel, Anguilla anguilla L. It was then shown to infect fibrocytes and cause dermatitis (herpesviral dermatitis) in Japanese eels, A. japonica Temminck \& Schlegel (Kobayashi and Miyazaki 1997). HVA was later found in Taiwan, isolated from diseased cultured Japanese eels and designated as eel herpesvirus in Formosa (EHVF) (Ueno et al. 1992). In comparison of the two isolates, the results of producing identical cytopathogenic effect (CPE), similar susceptibilities of fish cell lines such as Tilapia ovary cells (TO-2), common carp fin cells (CF) or coloured carp testis cells (CCT) showed that they were indistinguishable. In addition, the serological similarity shown by the Western blot and the cross-neutralization test further supported the suggestion that they were tightly clustered. However, HVA and EHVF were distinctly different from the channel catfish virus $(\mathrm{CCV})$ on the basis of the neutralization test (Ueno et al. 1996).

A herpesviral gill disease accompanied by the mass mortality that occurred in A. japonica has recently been reported (Lee et al. 1999). This new isolate, tentatively designated as gill herpesvirus of eel (GHVE), although affecting mainly the gills rather than skin, was also identified as HVA by a neutralization test (Lee et al. 1999). HVA was also isolated from diseased, farmed European eels, A. anguilla, in the Netherlands and was shown to be antigenetically related to the Japanese isolate (van Nieuwstadt et al. 2001). The finding of recrudescence of HVA activated by exogeneous or endogeneous stresses supports the idea that HVA can establish a latent virus state in eels; the latent virus can subsequently be shed from the carrier fish without clinical signs (van Nieuwstadt et al. 2001).

To better understand as well as to permit the detection of the early stages of the HVA infection, HVA genomic DNA was cloned and a gene probe was developed in this study. After confirmation of the probe sensitivity and specificity, the probe was applied to detect the HVA genomes from infected cell cultures and infected eel specimens using the dot blot and in situ hybridizations.

\section{Materials and methods}

Cells, viruses and virus purification

Tilapia ovary cells (TO-2) were grown in L-15 medium (GIBCO-BRL, Cleveland, OH, USA) supplemented with $10 \%$ fetal bovine serum (FBS), penicillin $\left(100 \mathrm{IU} \mathrm{ml}^{-1}\right)$, streptomycin $\left(100 \mu \mathrm{g} \mathrm{ml}^{-1}\right)$ and amphotericin $\mathrm{B}\left(0.25 \mu \mathrm{g} \mathrm{ml}^{-1}\right)$ in $175 \mathrm{~cm}^{2}$ tissue culture flasks (Nunc, Roskilde, Sweden). HVA Taiwan isolate (formerly EHVF, Ueno et al. 1992) was cultured in TO-2 cells at $20^{\circ} \mathrm{C}$ supplemented with $2 \%$ FBS Herpesvirus cyprini (CHV) was cultured in fathead minnow (FHM) cells and grown in Eagle's minimum essential medium (MEM) (GIBCO-BRL) supplemented with 2\% FBS. Approximately 0.51 culture fluids containing each virus was collected after 7 days incubation. Virus purification was performed as reported by Ueno et al. 1996.

\section{DNA isolation}

The viral DNA was extracted by adjusting the purified viral suspension to $10 \mathrm{mM}$ Tris- $\mathrm{HCl}, 1 \mathrm{mM}$ ethylenediamine tetraacetic acid (EDTA), $1 \mathrm{mM} \mathrm{KCl}, 10 \%$ SLS (sodium lauroylsarcosin), $\mathrm{pH}$ 8.0, and adding Proteinase $\mathrm{K}$ to a final concentration of $100 \mu \mathrm{g} \mathrm{ml} l^{-1}$. Following incubation at $65^{\circ} \mathrm{C}$ for $3 \mathrm{~h}$, the DNA was extracted with an equal volume of phenol 2-3 times, followed by an equal volume of chloroform/ isoamyl alcohol once. The DNA was recovered by ethanol precipitation, dried and resuspended in $200 \mu \mathrm{l}$ of TE $(10 \mathrm{mM}$ Tris, $1 \mathrm{mM}$ EDTA, pH 7.5) buffer at $65^{\circ} \mathrm{C}$ for $15 \mathrm{~min}$, and then stored at $4{ }^{\circ} \mathrm{C}$ until used. Total cell DNA was isolated from infected and mock-infected TO-2 cells using the same protocol. DNA concentrations were measured with a GeneQuantIIRNA/DNA calculator (Pharmacia Biotech, Uppsala, Sweden); the final concentration of extracted HVA DNA was adjusted to be $2.0 \mathrm{mg} \mathrm{ml}^{-1}$.

\section{Cloning, preparation of DNA probe and DNA sequencing}

The HVA DNA $(100 \mu \mathrm{g})$ and plasmid pUC19 $(10 \mu \mathrm{g})$ (BioLabs, New England) were respectively, digested with a restriction enzyme, HindIII (Boehringer Mannheim, GmbH, Mannheim, Germany) at $37^{\circ} \mathrm{C}$ for $3 \mathrm{~h}$ using one unit of enzyme per $\mu \mathrm{g}$ DNA. Two digested DNA were mixed and ligated using T4 DNA ligase (Promega) according to the manufacturer's directions. The reaction was carried out at 
$20^{\circ} \mathrm{C}$ for $16 \mathrm{~h}$. Escherichia coli strain DH- $5 \alpha$ competent cells (GIBCO BRL) were transformed with the recombinant plasmid after incubation in an ice bath for $30 \mathrm{~min}$ and $42^{\circ} \mathrm{C}$ for $2 \mathrm{~min}$. Transformant selection was carried out on Luria Broth (LB) agar plates (16 g Bacto tryptone, $10 \mathrm{~g}$ Bacto yeast extract, $5 \mathrm{~g} \mathrm{NaCl}$, and $15 \mathrm{~g}$ agarose per liter) containing $50 \mu \mathrm{g} \mathrm{ml}^{-1}$ of ampicillin, $50 \mathrm{mg} \mathrm{ml} \mathrm{m}^{-1}$ of X-gal (5-bromo-4chloro-3-indolyl- $\beta$-D-galactopyranoside) and $20 \mathrm{mg} \mathrm{ml}^{-1}$ Isopropyl thiogalactoside (IPTG).

White colonies were selected and replated. Isolated plasmid DNA was digested with HindIII, subsequently analyzed by electrophoresis in $1 \%$ agarose gels along with a HindIII digest of HVA DNA. Colonies assumed to carry plasmid with recombinant HVA DNA inserts were identified and later grown in LB medium.

Large amounts of recombinant plasmid DNA were purified using the method of Holmes and Quigley (1981). The purified DNA was then digested with HindIII and electrophoresed in a $1 \%$ agarose gel. After staining with ethidium bromide, the putative HVA bands were electrophoretically eluted using an Electro-elution concentrator (CBS Scientific Comp. Inc. Del Mar, CA, USA) at $150 \mathrm{~V}$ for $3 \mathrm{~h}$. The DNA was purified with phenol/chloroform protocol and dissolved in TE. The sequence of the cloned fragment was obtained with a Taq DiDeoxy Terminator Cycle Sequencing kit from Applied Biosystems (Foster City, CA, USA).

The DNA probe was labeled with digoxigenin (DIG)-11dUTP using a random primed reaction according to the manufacturer's instructions (Boehringer Mannheim).

\section{Southern hybridization}

DNA purified from recombinant clones was digested with HindIII and then electrophoretically separated in $1 \%$ agarose gel. After acid $(0.25 \mathrm{~N} \mathrm{HCl})$ depurination and alkali $(1.5 \mathrm{M}$ $\mathrm{NaCl}, 0.5 \mathrm{~N} \mathrm{NaOH}$ ) denaturation of the DNA, the gel was neutralized with $1 \mathrm{M}$ Tris $(\mathrm{pH} 7.4)$ and $1.5 \mathrm{M} \mathrm{NaCl}$, and subsequently transferred to a Hybond-N nylon membrane (Amersham Biosciences, Buckinghamshire, UK) using a transfer unit (Hoefer, Uppsala, Sweden) for $1 \mathrm{~h}$. $20 \times \mathrm{SSC}$ $(1 \mathrm{x} \mathrm{SSC}=150 \mathrm{mM} \mathrm{NaCl}, 15 \mathrm{mM}$ sodium citrate, $\mathrm{pH} 7.0)$ was used as the transfer buffer. HVA DNA digested with HindIII proceeded in parallel.

The nylon membrane was pre-hybridized at $37^{\circ} \mathrm{C}$ for $2 \mathrm{~h}$ in standard hybridization solution $[50 \%$ formamide, $5 \times \mathrm{SSC}$, $2 \%$ Blocking reagent, $0.1 \% \mathrm{~N}$-lauroylsarcosine, $0.02 \%$ sodium dodecyl sulfate (SDS), $\mathrm{pH}$ 7]. The probe was boiled for $5 \mathrm{~min}$ cooled on ice, diluted in standard hybridization solution to a final concentration of $25 \mathrm{ng} \mathrm{ml}{ }^{-1}$, and added to the membrane. The hybridization was carried out at $42^{\circ} \mathrm{C}$ in a shaking water bath for approximately $16 \mathrm{~h}$. After hybridization, the detection of the DIG-labeled nucleotides in blots was accomplished with an alkaline phosphatase-conjugated anti-DIG antibody (Kirkegaard \& Perry Laboratories, Inc., Gaithersburg, MD) and a substrate/indicator solution, nitroblue tetrazolium (NBT) and X-phosphate (5-bromo-4-chloro-3indoyl phosphate), according to the manufacturer's instructions. Briefly, the membrane was incubated with $150 \mathrm{mU} \mathrm{ml}^{-1}$ anti-DIG conjugate at room temperature for $30 \mathrm{~min}$. After washing with maleic acid buffer $(0.5 \mathrm{M}$ maleic acid, $0.15 \mathrm{M}$ $\mathrm{NaCl}, \mathrm{pH}$ 7.5) twice, the membrane was dipped into the substrate/indicator solution in the dark for $5 \mathrm{~h}$. A positive reaction was recognized by the presence of a blue to dark purple precipitate in the nylon membrane.

\section{Dot blot hybridization analysis}

The HVA DNA was serially diluted, denatured and spotted onto a nylon membrane. After cross-linking the DNA with the membrane at 120 mjoles $\mathrm{cm}^{-2}$ for 2 min using UV light (Electronic UV Crosslinker, ULTRA.LUM), the blot was used for hybridization with an HVA probe to assay its sensitivity as in the Southern hybridization. DNA samples extracted from the HVA-infected, uninfected TO-2 cells and CHV-infected FHM cells were used to assay the specificity of the probe.

\section{In situ hybridization}

HVA detection by in situ hybridization was primarily tested in cell cultures. TO-2 cells were grown on chamber slides (Corning, Tokyo, Japan) and fixed in acetone for $10 \mathrm{~min}$. The slides were treated for 15 min with $100 \mu \mathrm{g} \mathrm{ml}^{-1}$ Proteinase $\mathrm{K}$ in phosphate buffered saline (PBS) at $37^{\circ} \mathrm{C}$. After washing with $0.2 \%$ glycine (in PBS), the slides were covered with hybridization buffer containing $50 \%$ formamide, $5 \%$ dextran sulfate, $4 \times \mathrm{SCC}, \quad 0.2 \mathrm{mg} \mathrm{ml}^{-1}$ salmon sperm DNA and $10 \mathrm{ng} \mathrm{ml}^{-1}$ DIG-labeled probe. Each slide was covered with a coverglass, sealed with vinyl tape, placed inside a plastic bag and immersed in a $90^{\circ} \mathrm{C}$ water bath for $10 \mathrm{~min}$. The slides were then transferred to a $37^{\circ} \mathrm{C}$ incubator and hybridized for 16-24 h. After hybridization, detection and coloration of DIG-labeled DNA were as described in the Southern hybridization. The slides were counterstained with $1 \%$ aqueous neutral red, rinsed with water and temporally mounted for observation.

\section{Experimental infection of eels}

The Japanese eels (average weight $14.9 \mathrm{~g}$ ) were all HVA polymerase chain reaction (PCR) negative as examined by a protocol described by Shih (2002). Each eel was injected intraperitoneally with $0.1 \mathrm{ml}$ virus suspension containing $10^{3.25}$ TCID $_{50} \mathrm{ml}^{-1}$. The control eels were injected with L15 medium containing $2 \%$ FBS instead of the virus suspension. After the injection, the fish were held in aquaria at $25^{\circ} \mathrm{C}$. Gills and livers were collected and fixed in $10 \%$ phosphate-buffered formalin at 1-week intervals until the end of the 7-week experiment. Fixed samples were embedded in paraffin wax and sectioned. Seven micrometer sections were placed onto slides pre-coated with $2 \%$ silane (r-methacryloxypropyl tri-methoxysilane). The sections were deparaffinized and rehydrated using the standard methods, and digested with $100 \mu \mathrm{g} \mathrm{ml}^{-1}$ Proteinase $\mathrm{K}$ in PBS at $37^{\circ} \mathrm{C}$. The slides were then hybridized and visualized as described above.

\section{Results}

\section{Cloning of HVA genomic DNA}

HVA DNA was digested with HindIII and electrophoresed in a $1 \%$ agarose gel. More than 20 bands could be seen in the gel (Fig. 1A, lane 1). A fragment of 1550 bp was selected for use in probe production, which was designated as H1-1. A HindIII digest of this recombinant plasmid, named as clone $\mathrm{pH} 1-1$, was shown along with a HindIII digest of HVA DNA. The ligated HVA fragment of H1-1 (Fig. 1A, lane 2) aligned with a 1550-bp band observed in the HindIII digest of HVA DNA (Fig. 1A, lane 1). H1-1 was confirmed as being HVA DNA by hybridizing a gel-purified probe labeled with DIG to a Southern blot of HindIII digested HVA DNA. The results 
A

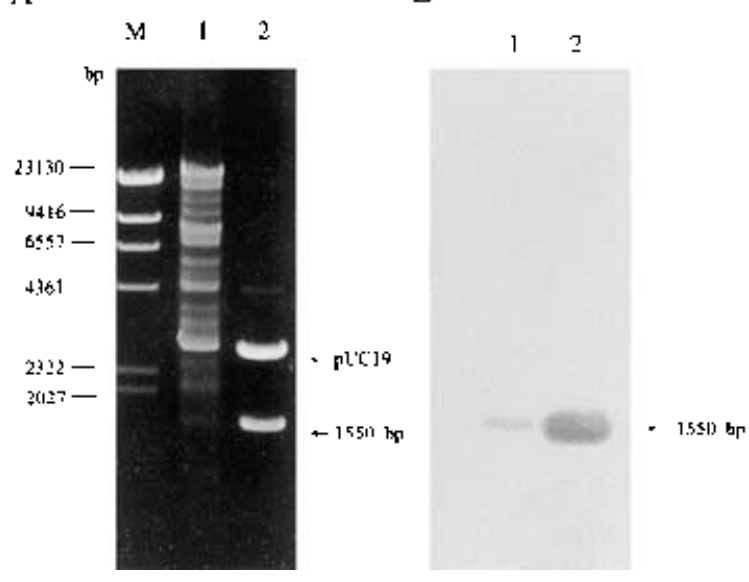

Fig. 1. Restriction profiles of purified DNA and Southern blot hybridization analysis. (A) Ethidium bromide-stained $1 \%$ agarose gel. Lane 1: HindIII digest of HVA DNA. Lane 2: HindIII digest of recombinant plasmid, $\mathrm{pH} 1-1$. The lower band aligns with a 1550-bp band of the HindIII digest of HVA DNA. The middle band is the linear vector $\mathrm{pUC19}$, and the upper band is the trace of the uncut $\mathrm{pH} 1-1$. (B) Southern blot of HindIII digests of HVA and pH1-1 DNA probed with DIG-labeled H1-1. Lane numbers correspond to the DNA sample numbers used in (A). M: lambda phage DNA HindIII fragments

can be seen in Fig. 1B, lane 1. A much stronger reaction was observed as this probe hybridized to its original DNA (Fig. 1B, lane 2).

\section{Restriction map and sequence of H1-1}

The insert of clone $\mathrm{pH} 1-1$ was characterized by restriction enzyme mapping and nucleotide sequencing (Fig. 2). The H1-1 DNA sequence was subjected to BLAST analysis to identify homologous sequences in databases (GenBank). No homologous sequences were found. Six partially open reading frames (ORF) were identified (data not shown).

\section{Sensitivity and specificity of probe H1-1}

The dot blot hybridization results revealed that $1 \mathrm{pg}$ of HVA DNA can be readily detected by probe H1-1 (Fig. 3A, dot 4). No cross-reactivity was observed with uninfected TO-2 DNA (Fig. 3B, dot 4) or CHV-infected FHM DNA (Fig. 3B, dot 5). HVA infection in vitro could be demonstrated as early as $12 \mathrm{~h}$ post-infection (pi) (Fig. 3B, dot 3). Stronger reactions were shown at 24 and $48 \mathrm{~h}$ pi, respectively (Fig. 3B, dots 2 and 1).

\section{Confirmation of HVA by in situ hybridization}

The results of in situ hybridization showed that HVA genome could be successfully detected by probe H1-1 in HVA-infected TO-2 cells as early as $3 \mathrm{~h}$ pi (data not shown), positive reactions were evident at $24 \mathrm{~h}$ pi (Fig. 4A). No reactions were shown in the control (Fig. 4B). In both gill and liver paraffin sections, the HVA genome was readily detected by in situ hybridization at 4 weeks pi where histopathological signs were not evident (Fig. 5). Gill filaments had hemorrhages within the

A

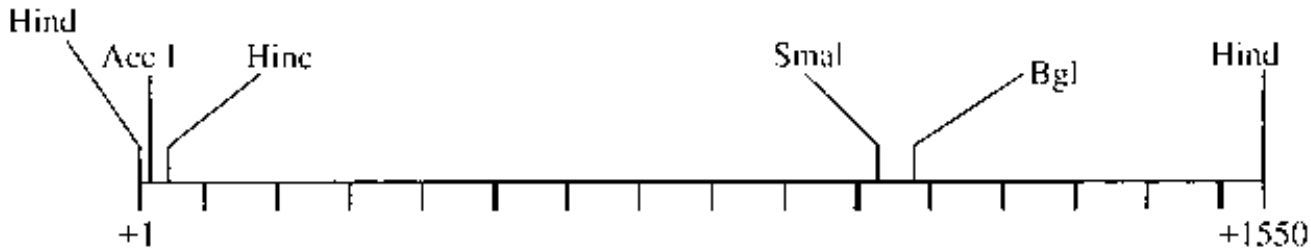

\section{B}

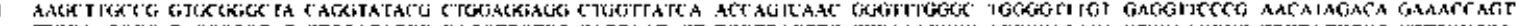

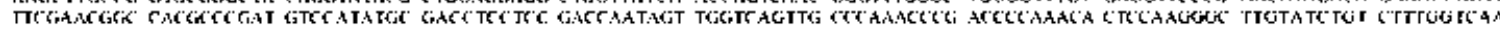

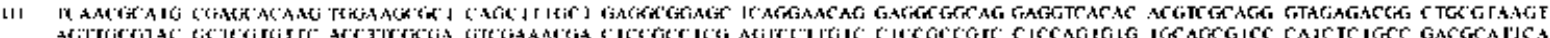

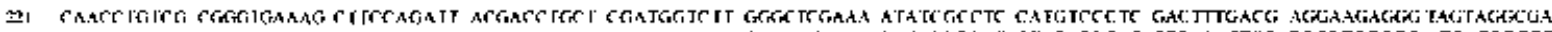

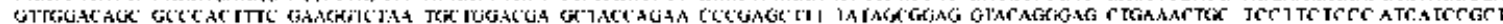

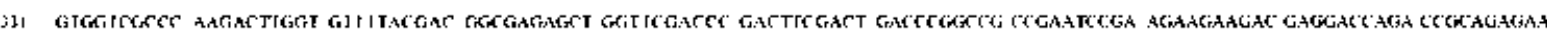

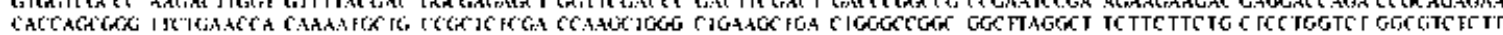

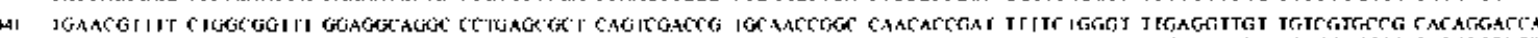
ACTre Ahth GitCo

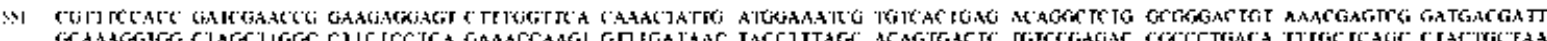

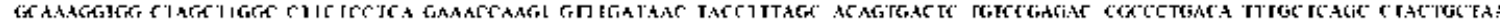

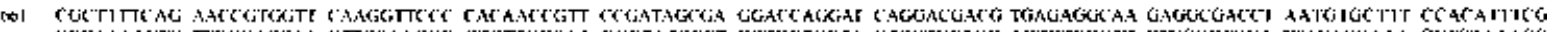

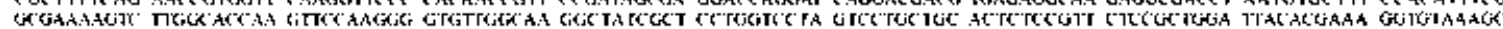

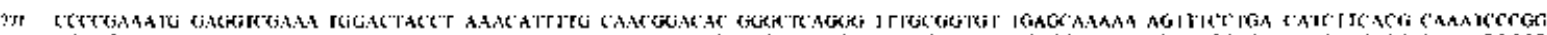

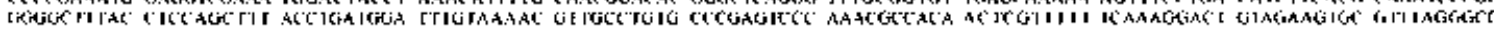

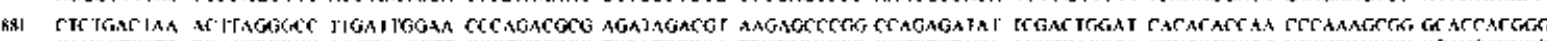

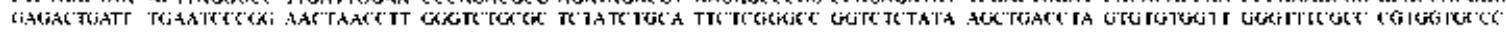

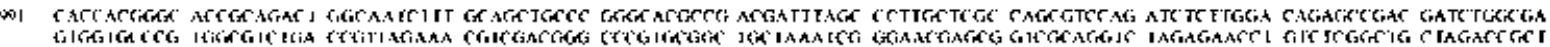

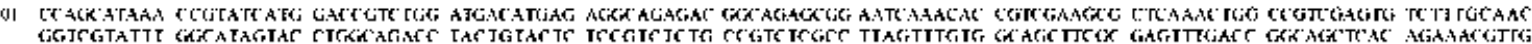

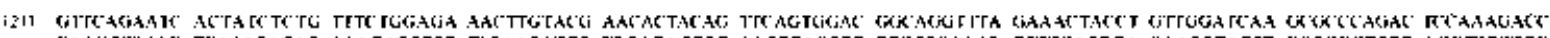

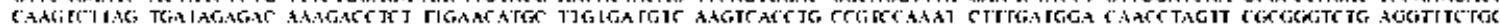

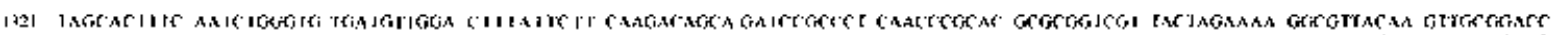

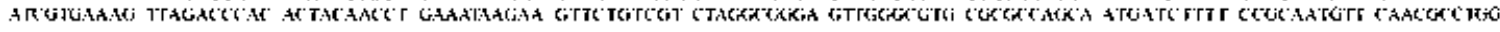

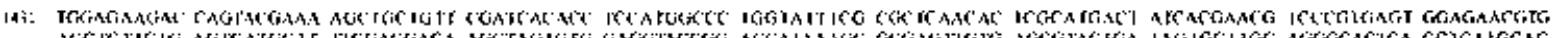

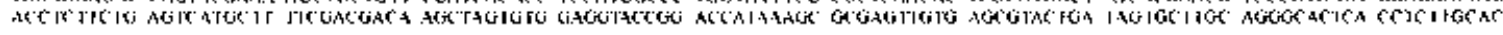

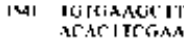

Fig. 2. Restriction enzyme map (A) and nucleotide sequence (B) of the DNA insert, H1-1, in plasmid pH1-1. The positions of restriction sites of H1-1 are $A c c$ I at +23 , HincII at +54 , SmalI at +1030 , and $B g / \mathrm{II}$ at +1062 , respectively 


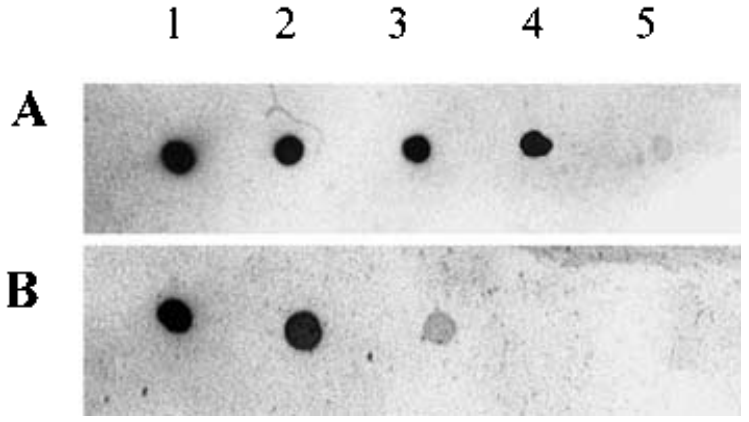

Fig. 3. Sensitivity and specificity of probe H1-1. (A) Dot hybridization assay on sensitivity of H1-1 probe. Tenfold serial dilution of HVA DNA denatured by boiling were spotted onto nylon membrane and probed with H1-1. Dot 1: contains 1 ng of HVA DNA; Dot 2: contains $0.1 \mathrm{ng}$ of HVA DNA; Dot 3: contains $0.01 \mathrm{ng}$ of HVA DNA; Dot 4: contains $1 \mathrm{pg}$ of HVA DNA; and Dot 5: contains $0.1 \mathrm{pg}$ of HVA DNA, respectively. (B) Dot hybridization assays on HVA-infected TO-2 DNA collected at various periods post-infection (pi) and on CHV-infected FHM DNA. Dot 1: DNA of HVA-infected TO-2 cells, $48 \mathrm{~h}$ pi; Dot 2: $24 \mathrm{~h}$ pi; Dot 3: $12 \mathrm{~h}$ pi; Dot 4: DNA of uninfected TO-2 cells; Dot 5: DNA of CHV-infected FHM cells. Each dot contains $0.1 \mathrm{ng}$ DNA denatured by boiling and probed by H1-1 probe
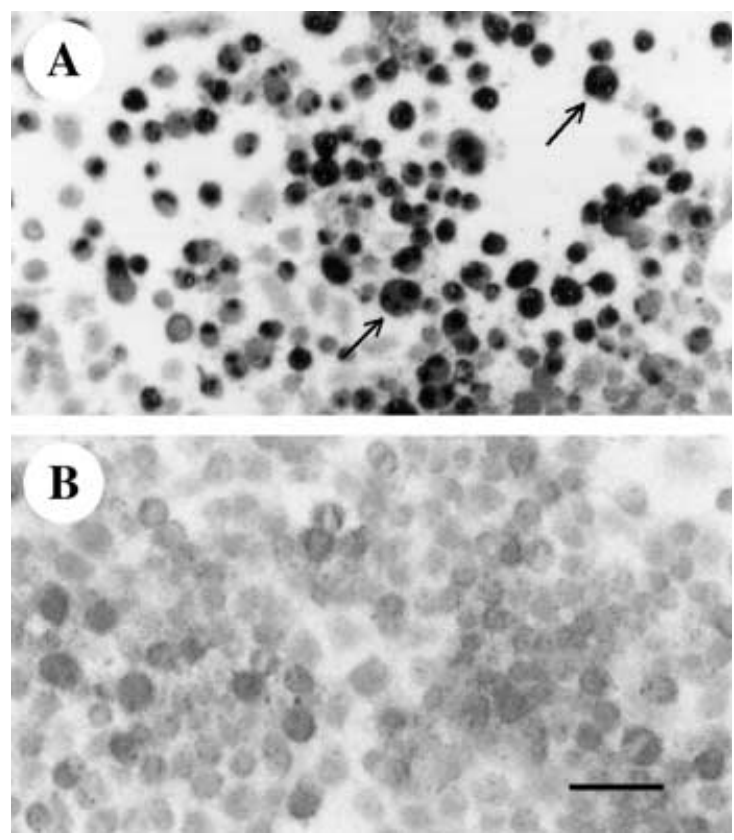

Fig. 4. Detection of viral genome in HVA-infected TO-2 cells by in situ hybridization with H1-1 probe. (A) Strong positive signals shown in infected cells at $24 \mathrm{~h}$ pi are distinguishable from the uninfected cells. Multinuclear syncytia are abundant (arrows). (B) Negative control shows no signals in infected TO-2 cells probed with hybridization solution only. Bar indicates $50 \mu \mathrm{m}$

central region and the infected but non-necrotic fibrocytes of the connective tissue showed positive signals (Fig. 5A). Infected hepatic cells were easily distinguishable from the uninfected eel liver cells (Fig. 5B). Although the positive signal was primarily nuclear, a positive reaction was also evident in the cytoplasm in cell culture and sectioned samples.

\section{Discussion}

Specific nucleic acid probes have been developed to detect fish herpesvirus DNA in sick or latent infected fish. A nucleic acid
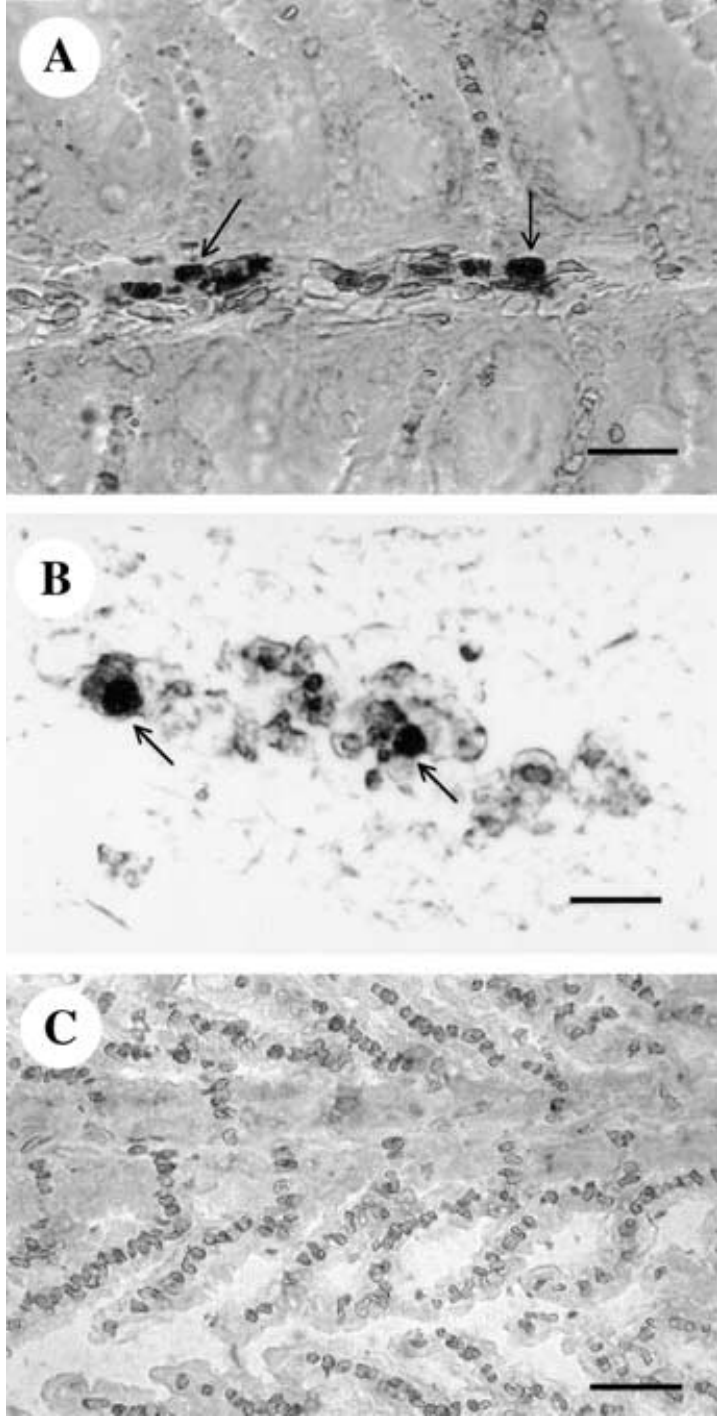

Fig. 5. Detection of HVA genome in gill (A) and liver (B) tissue sections prepared from experimentally infected Japanese eels, Anguilla japonica by in situ hybridization with H1-1 probe. Positive signals are observed in fibrocytes (arrows) within the central region of gill filament in (A) and the hepatic cells (arrows) in (B). Negative control of the gill (C) from uninfected eel showing no signals as probed with H1-1. Bars indicate $20 \mu \mathrm{m}$ in $(\mathrm{A}, \mathrm{B})$ and $25 \mu \mathrm{m}$ in $(\mathrm{C})$

probe for $\mathrm{CCV}$ was constructed using recombinant DNA techniques (Wise and Boyle 1985), and was successfully used to detect this virus in asymptomatic adult channel catfish, Ictalurus punctatus Rafinesque (Wise et al. 1985). This technique had been shown to be superior to the traditional techniques such as fluorescent antibody and co-cultivation methods. DNA probes were also cloned from the $O$. masou virus (OMV) genome and were successfully applied for viral detection in salmon which were experimentally infected for 1 week, using Southern blot analysis (Gou et al. 1991). Probes constructed from CHV DNA worked well in detecting viral genomes from many organs of either clinically infected carp or carriers by in situ hybridization (Sano et al. 1992, 1994).

We report successful construction and use of a specific probe, H1-1, for the detection of HVA Taiwan isolate DNA. The sensitivity of this probe is about $1 \mathrm{pg}$ viral DNA, which is sufficient to detect viral genomes in infected samples. H1-1 was applied to the detection of HVA DNA in infected TO-2 cells. 
Positive results showed as early as $12 \mathrm{~h}$ pi by dot blot hybridization and $3 \mathrm{~h}$ pi by in situ hybridization (data not shown; a higher density of positive cells from $24 \mathrm{~h}$ pi sample is shown in Fig. 4a). No reaction was observed in uninfected TO-2 cells or CHV-infected FHM cells. In addition, infected fibrocytes of gill filament and hepatic cells were easily distinguishable from uninfected cells by in situ hybridization using this probe. Positive signals were observed within these tissues with no evidence of histopathological signs. No reactions were shown in the negative control. These results illustrate that the H1-1 probe is specific and sensitive for detection and identification of HVA DNA in the early stages of infection. Considering its sensitivity, this probe might capably be applied for the detection of latent HVA in asymptomatic eels.

A search in the GenBank did not reveal any sequences homologous to that of the H1-1 described herein. This may be the result of the fact that very few viral sequences of fish herpesviruses have been submitted and that HVA has a large genome of approximately $188 \mathrm{kbp}$ estimated from the mean of its restricted endonuclease profiles with HindIII, KpnI, PstI, and SmalI (Shih et al. 1993). Other clones will be continuously screened and analyzed.

Taiwan and Japan HVA isolates, which were shown to share common CPE, morphology, size, and serological characteristics (Ueno et al. 1996), were recognized to have weak pathogenicity to eels and to affect primarily the eel skin (Sano et al. 1990; Ueno et al. 1992). A distinct pathogenicity affecting the eel gills was reported. A gill disease was proposed and named herpesviral gill filament necrosis; the putative virus, GHVE, was also identified as HVA by a neutralization test (Lee et al. 1999). Using the H1-1 gene probe cloned in this study, HVA DNA was detected from gill and liver of experimentally infected eels inoculated with a low titer of HVA Taiwan virus. But pathological changes reported in GHVE infection, such as the extensive necrosis of the connective tissue in the gill filament and hepatic congestion (Lee et al. 1999), were not observed until 7 weeks pi. This probe could be useful in determining the similarity of these isolates and may provide a new, sensitive tool for the diagnosis of these diseases.

\section{Acknowledgements}

The authors thank Mr Fu-Ming Pan, Institute of Biochemistry, Sinica Academia, for his kind assistance in the DNA sequencing. This study was supported by research grants $87-$ AST-1.4-FID-06(10) and NSC 85-2311-B-002-041.

\section{References}

Gou, D. F.; Kubota, H.; Onuma, M.; Kodama, H., 1991: Detection of salmonid herpesvirus (Oncorhynchus masou virus) in fish by Southern blot technique. J. Vet. Med. Sci. 53, 43-48.

Holmes, D. S.; Quigley, M., 1981: A rapid boiling method for the preparation of bacterial plasmids. Ana. Biochem. 114, 193-197.

Kobayashi, T.; Miyazaki, T., 1997: Characterization and pathogenicity of a herpesvirus isolated from cutaneous lesion in Japanese eel, Anguilla japonica. Fish Pathol. 32, 89-95. (In Japanese).

Lee, N.-S.; Kobayashi, J.; Miyazaki, T., 1999: Gill filament necrosis in farmed Japanese eels, Anguilla japonica (Temminck \& Schlegel), infected with Herpesvirus anguillae. J. Fish Dis. 22, 457-463.

van Nieuwstadt, A.P.; Dijkstra, S.G.; Haenen, O.L.M., 2001: Persistence of herpesvirus of eel Herpesvirus anguillae in farmed European eel Anguilla anguilla. Dis. Aquat. Org. 45, 103-107.

Sano, M.; Fukuda, H.; Sano, T., 1990: Isolation and characterization of a new herpesvirus from eel. Pathol. Marine Sci. 1, 15-31.

Sano, N.; Sano, M.; Sano, T.; Hondo, R., 1992: Herpesvirus cyprini : Detection of the viral genome by in situ hybridization. J. Fish Dis. 15, 153-162.

Sano, N.; Moriwake, M.; Hondo, R.; Sano, T., 1994: Herpesvirus cyprini: A search for viral genome in infected fish by in situ hybridization. J. Fish Dis. 16, 495-499.

Shih, H. H., 2002: Detection of Herpesvirus anguillae DNA in cultivated eels using the polymerase chain reaction. Res. Appl. Biotech. Aqu. 3, 177-183.

Shih, H. H.; Lu, C. C.; Chen S. N., 1993: Eel herpesvirus in Formosa: a herpesvirus from cultured Japanese eel. Reports Fish Dis. Res. 13, 86-96 (in Chinese with English abstract).

Ueno, Y.; Kitao, T.; Chen, S. N.; Aoki, T.; Kou, G. H., 1992 Characterization of a herpes-like virus isolated from cultured Japanese eels in Taiwan. Fish Pathol. 27, 7-17.

Ueno, Y.; Shi, J. W.; Yoshida, T.; Kitao, T.; Sakai, M.; Chen, S. N.; Kou, G. H.., 1996: Biological and serological comparisons of eel herpesvirus in Formosa (EHVF) and Herpesvirus anguillae (HVA). J. Appl. Ichthyol. 12, 49-51.

Wise, J. A.; Boyle, J. A., 1985: Detection of channel catfish virus in channel catfish, Ictalurus puncatus (Rafinesque): use of a nucleic acid probe. J. Fish Dis. 8, 417-424.

Wise, J. A.; Bowser, P. R.; Boyle, J. A., 1985: Detection of channel catfish virus in asymptomatic adult channel catfish, Ictalurus puncatus (Rafinesque). J. Fish Dis. 8, 485-493.

Author's address: Dr Hsiu-Hui Shih, Department of Zoology, National Taiwan University, Taipei, Taiwan.

E-mailshihhh@ccms.ntu.edu.tw 